UDC 33.137 .22

\author{
Sedikova I. \\ Doctor of Economics, Associate Professor \\ E-mail: irina-sedikova@rambler.ru \\ Savenko I. \\ Doctor of Economics, Professor \\ Department of Management and Logistics \\ Odessa National Academy of Food Technologies \\ Kanatna str., 112, Odesa, Ukraine, 65039 \\ E-mail: kaf-ml@mail.ru
}

\title{
ANALYSIS OF LEGAL FORMS STRUCTURAL ELEMENTS OF GRAIN LOGISTICS
}

The article analyzes some aspects of the development of vertically integrated structure of the grain sub analyzed national experience of these sub grain structures are considered the most common model of integrated units of the grain market. In modern terms, «integration» becomes multifunctional character and is used to describe the various spheres of economic reality. The analysis of organizational and economic conditions for the functioning of logistics systems in sub zernoproduktov, defined functional areas of logistics in zernoproduktov subdivision. It is proved that each specific functional areas is the result of the transformation processes in the economy or start-ups to meet the business interests of their respective owners. It is proved that the most optimal logistic functions are implemented in terms of integrated structural elements of different legal forms.

Key words: grain logistics, logistic system, agroholding, exports, agricultural

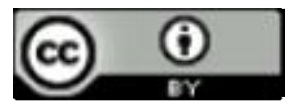

This work is licensed under a Creative Commons Attribution 4.0 International License http://creativecommons.org/licenses/by/4.0/

Statement of the problem and its connection with important scientific and practical tasks. Favorable conditions for grain production in Ukraine is the basis for the formation of a strong export-oriented industry that could provide the state budget with stable source of foreign currency. Complex social and economic conditions in Ukraine in 2014 against the backdrop of a tense military and political situation and the annexation of the Crimea, loss of control over the grain terminals of the peninsula, instability and fighting in south-eastern regions of the state, as well as temporary opening of the European market for Ukrainian products based on unilateral trade preferences pose new completely requirements for the national economy, particularly grain-food subcomplex.

Quantitative parameters of grain-food market in Ukraine are influenced by aggregate of organizational and economic conditions in which we include structural elements of different legal forms and economic instruments that provide exchange processes for stable functioning and effective development of all components of the supply-side system. Logistic system integrates the efforts of individual elements in a single chain, which functions on the basis of economic compromises and provide movement of the material flow from raw materials base through processing to the final consumer of finished products. Internal control logistics system is defined by organizational and structural, functional and economic, social and consumer factors that actually is the starting point for the improvement of the system.

The analysis of the latest publications on the problem. Separate aspects of the process of development of vertically integrated structures of the grain subcomplex have been studied by many Russian scientists, in particular, the issues of the advantages of vertical integration have been devoted the works by I. Lukinov, A. Onischenko, P. Sabluk, I. Savenko, V. MeselVeselyak, V. Andriychuk, M. Kropivko, V. Boyko, O. Krisalny and others. The problems of development of agricultural holdings were investigated by V. Geyets, A. Borodina, I. Kryuchkova, S. Demyanenko, O. Erankin, O. Sadovnik, O. Lissitsa. Among foreign scholars, we should pay attention to the works of E. Serov, I. Minakova, I. Ushachov, J. Yakovtsya, I. Khramovoy, S. Gubanov, T. Keller, G. Hockman and others.

Forming of the aims of the research. The purpose of the article is to analyze the domestic experience in the development of vertically integrated structures of the grain subcomplex and consider the most common models of integrated grain market formations.

Giving an account of the main results and their substantiation. The concept of integration (from the Latin word integer - whole), is now widely distributed and used in various fields. For the first time in general economic science, a quantitative measure of integration was introduced and used in the works of A. Marshall, 
who used this indicator as a «generalized characteristic of the state of the capitalist economic system during the formation of corporations» [2, p. 315].

In modern conditions, the term «integration» acquires a multifunctional character, and it is used in describing of various spheres of economic reality. In some works, it is noted that «integration is an association of economic entities or deepening of interaction between them, while in the role of subjects national economies and enterprises» can act [1, p. 7].

It is known, that agroholdings are created by a non-agricultural business. In some cases, this business is directly related to agriculture, in others - it is created by a company not related to agriculture. As the scientists note, «the formation of diversified structures has affected all sectoral subcomplexes ... The difference is in the scale and pace of development of property forms, the proportions of the combination of property integration mechanisms within specific industries ...» $[3, \mathrm{p} .14]$.

Analysis of organizational and economic conditions for the functioning of logistics systems in the graingrocery subcomplex AIC should start with a review of existing types of business entity, which in our opinion are a form of economic activity with the appropriate legal basis which defines the relationship between the parties, the regime of property liability for obligations of the company as well as the establishment, funding sources, activity management system, reorganization, liquidation and distribution in profits, etc.

Functional areas of logistics in grain-grocery subcomplex AIC is the production of grain, its implementation and therefore procurement of grain processors, grain storage with a possible transshipment in the ports for export grain mass processing and sale of processed products. Each of the defined functional areas covering the current set of elements (companies and organiza-

So the most optimal logistic functions are implemented in terms of integration of structural elements of different legal forms. Therefore, the trend of globalization of the world market results in association of large companies, enterprises, societies and funds in the relevant markets with the purpose of joint economic activities or coordination.

In addition to vertical integration in the form of holdings that actually control the entire logistics chain of passing grain flow from its production to sale of grain and grain processing products in domestic and foreign markets, is also developed in agriculture horizontal integration [14].

In practice, a holding company or vertically integrated cooperation means a set of companies in which the parent company and its subsidiaries or branches are differentiated. The parent company, as a rule, is represented by an economic company that controls the activities of legally independent subsidiaries through a controlling interest. The practice of recent years shows that the effectiveness of the organization of vertically integrated agribusiness in the conditions of our country depends, first of all, on the clarity and transparency of the rules and norms of the legal regulation of the ownership structure and the system for regulating the activities of such structures. 45 agrarian companies jointly control tions), results from the transformation processes in the economy or start-ups to meet the business interests of their respective owners. The first in the path of the grain flow is its direct generators - agricultural producers.

Stratification of the agricultural production caused a variety of legal forms of agricultural enterprises engaged in the production of grain and leguminous cultures and various forms of property and production scale. The appeal of grain production in Ukraine identifies a significant share in the structure of commodity production of the vast majority of businesses. Among 55,858 active farms, only 37,200 grew grains and legumes. The most successful are large export-oriented companies with vertically integrated production structure.

Currently, integration processes have become widespread in industries with a high degree of concentration and mechanization: the production and distribution of grain, sugar beet, sunflower seeds, poultry. In 2015, wheat production in holdings amounted to $6,300,000$ tonnes or almost $24 \%$ of total production in Ukraine. Despite the decline in yield, the production of wheat in agricultural holdings increased by $20 \%$ compared to last year due to an increase in acreage. Profitableness of production in agroholdings in 2015 - 5,2 thousand UAH from 1 ha $(+57 \%$ by 2014$)$. Over the past 5 years, wheat production in agroholdings has increased by $23 \%$ due to higher yields.

The leader in wheat production in Ukraine in 2015 was Vinnytsia region - 2200 thousand tons, which corresponds to the need for imports of the countries such as Iraq and Tunisia, or a third of EU imports. The volume of exports of agricultural holdings of wheat in 2015 amounted to 797 million dollars and 4,700 thousand tons, total number that supplied to Egypt - \$129.2 million, Thailand - \$ 97.2 million and Indonesia - \$ 70.6 million [11].

about 4.1 million hectares of agricultural land, and their total revenues exceed $\$ 10.8$ billion. Below are the characteristics of some of the largest holding companies in Ukraine.

«Kernel». Revenue: \$ 2329.5 million Segment: oil, cereals.

The Agroholding, the largest producer of vegetable oil in Ukraine in the II-nd quarter of 2016 marketing year increased profit by 2,7 times, to $\$ 117,75$ million. Seven plants of the company process about 3 million tons of sunflower seeds. The Holding is actively seeking new ways of development, as well as sales markets. For example, Kernel has already received permission to export corn to China. In 2016, the company started producing rapeseed oil at its two plants. Kernel actively invests in technology. Now he is modernizing Transbalkterminal and two grain elevators in the Chernigov region, the company sold the elevator in Nikolaev for \$ 993,000. At the same time, the agroholding is expanding its capacities in Ukraine: at the end of February 2016 for \$ 96 million Kernel bought the Hellada plant in Kirovograd Area, which previously belonged to the company «Creative». The capacity of the oil extraction plant «Ellada» is 560 thousand tons of sunflower a year. With a land bank of 390 thousand hectares, Kernel is one of the three largest 
agroholdings in Ukraine. The main crops are wheat, corn and sunflower. In 2015, Kernel increased grain sales by $12 \%$ compared to 2014 , to a record volume of 4.744 million tonnes [4].

The «Nibulon». Revenue: \$ 946.4 million Segment: plant growing, grain trade.

The company «Nibulon» is one of the largest exporters of Ukrainian agrarian products. «Nibulon» handles 82,5 thousand hectares of land in 12 regions of Ukraine. The company specializes in the production of wheat of I-II grades. In total in 2015 the company collected 310 thousand. Tonnes of grain and oilseeds, the average yield of the early grain group was $43,3 \mathrm{c} / \mathrm{ha}$. In 2014/15 marketing year, Nibulon shipped 4,2 million tonnes of grain to foreign markets, and in 2015/16 MY the company increased grain exports by $18 \%$, to 5 million tonnes. The company works with 64 countries, particularly countries of the Middle East, Europe and Africa. In 2015, Nibulon began exporting grains and oilseeds to China, Thailand and Mexico. The holding company is assisted by its own fleet. The company also builds a transshipment terminal on the Yuzhny Bug River. Investments in the project will amount to about 450 million hryvnas. The new complex will allow to store 76 thus. tonnes of grain, and the capacity for shipping to water transport will be 12 thousand tons per day. «Nibulon» renders services for transportation to other traders. In 2014/15 MG, the company transported more than 1,4 million tons with its vessels. The management actively attracts international financing for the development of the agricultural holding. In the summer of 2015, the EBRD provided the company with a syndicated loan of $\$ 130$ million for investment projects for the development of exports, as well as logistics and infrastructure for the storage of cereals.

«Myronivsky Hliboproduct». Revenues: \$ 1183,3 million Segment: poultry, plant growing, meat processing.

In 2015, the proceeds of the agricultural holding Myronivsky Hliboproduct fell by $14 \%$, to $\$ 1,2$ billion. This was affected by the devaluation of the national currency. The company also reduced exports by $6 \%$, due to the closure of the Russian market. In 2015, MHP successfully exchanged assets with the Russian company Agrokultura, the agroholding changed 40,000 hectares of land and grain storage for 150,000 tons in the Voronezh Region, 60,000 hectares of land and storage for 90,000 tons of Agroculture in Lviv, Ivano-Frankivsk and Ternopil regions. In 2016, thanks to investments in the expansion of Mironovskaya poultry farm and poultry farm «OrelLeader», the agroholding will increase the production of chicken meat by 40 thousand tonnes MHP will also expand sales markets and increase export volumes, including in the regions traditional for the company: the CIS countries, the Middle East, the European Union. At the end of 2015, deliveries of about 10000 tonnes of poultry to the Saudi Arabian market were made. In the next two years, it is planned to increase the land bank by at least 50 thousand. ha up to 420 thousand hectares.

ViOil. Revenues: \$ 373.3 million Segment: oil. It is included in the TOP-3 of the largest Ukrai- nian producers and exporters of sunflower oil. On the territory of the Chernivtsi oil and fat plant, a new plant for processing soybean and rape with a capacity of 1100 tons and 1500 tons per day, respectively is going to be built. Until May 2017, the company plans to increase the capacity of the Vinnytsia fat and oil processing plant for processing sunflower by 600 tons per day, to 2800. This is the most powerful enterprise in the Ukrainian fat and oil industry in terms of processing volumes at one site. In the conditions of deficiency of sunflower seeds, the company envisaged the possibility to process three types of oilseeds: sunflower, rapeseed and soy. This allows it to fully load the power. Another part of the purchased raw materials ViOil gives to other factories under the tolling scheme. The company is the leader in the production of rapeseed oil in Ukraine. The main markets for ViOil are the countries of the CIS, the Middle East, Southeast Asia, Africa, Europe.

Agroprosperis. Revenues: \$ 293.1 million Segment: growing cereals.

The Agroprosperis group of companies, managed by the NCH Capital investment fund, collected 1.8 million tons of cereals and oilseeds in 2015. In the priority of the company there is corn, sunflower, wheat, rapeseed and soy. In the near future, Agroprosperis will concentrate on supplying seeds and plant protection products to farmers, and will also conclude contracts with foreign traders. Agroprosperis manages 430 thousand hectares in Kharkiv, Sumy, Vinnitsa and Khmelnytsky regions.

Effectively organized interaction of all participants of the integrated structure on the principles of logistics in the long term can have a positive synergetic effect if the contribution of each participant will be aimed at achieving the overall goal of the entire system. It is known from the works of the leading research scientists of integration processes in the grain subcomplex, «the main motive in creating holding units in the grain subcomplex is control over the activities of agricultural producers-suppliers of grain resources. The formation of sales structures, isn't less important, as well as the necessary logistics infrastructure».

In general, according to the data of the largest grain market companies, «the current situation in the grain market is characterized by a high degree of fragmentation of production, when the 10 largest grain holdings control no more than $10-15 \%$ of the infrastructure capacities of production and sale of grain resources in the country».

Creating of associations of enterprises in Ukraine is unique not only to basic logistics, which integrates vertical or horizontal grain producers and processors of it, but also for functional areas engaged in transportation, handling, storage units and providing logistics functions with material, information and financial resources . This list includes Carriers Association of Agricultural Ukraine, Ukrainian Logistics Association, the Association of forwarding and logistics organizations of Ukraine «Ukrzovnish-trans» and indirectly can include a variety of freight forwarding associations, financial, insurance, trade and many other companies. 
The state share of the companies in the graingrocery subcomplex AIC Ukraine is represented by such following organizational and legal forms, as a Public Joint Stock Company «State Food and Grain Corporation of Ukraine», State Agency reserve Ukraine (Grant) and the State Joint Stock Company «Bread of Ukraine».

Conclusions and prospects of the further investigations. So, regardless of ownership we further improvement of legal forms of structural elements of the logistics system see the in consolidation of their efforts through various associations. The effectiveness of these associations will be determined by implementation of logistics functions by high quality and lower costs than union members performed alone.

Consolidation of the financial resources of associations of enterprises creates technical and technological preconditions for the implementation of logistics functions at a new level. Agricultural technique is out of date and existing primitive technology of under floor storage units, lack of laboratory equipment for quality control, outdated equipment of grain processing enterprises, etc. all of these organizational and economic conditions for the operation of logistics systems in the grain-product subcomplex of Ukraine significantly reduce sectoral efficiency and significantly hinders the processes of integration into global logistics. In Ukraine, the ratio of current capacity silos for storing grain and primitive under floor technologies is $54,2 \%$ to $44,2 \%$, and the rest $(1,6 \%)$ is even outdated sack storage technology. The most potentially conflicting elements of the logistics chain in the grain-product subcomplex AIC is the relationship between grain producers and processors, and the relationship between production enterprises and its financial and credit institutions and other infrastructure and institutional elements that accompany the material and providing (Information, financial and service) flows.

\title{
References
}

1. Aiusheeva, A. O. (2013). Formyrovanye yntehryrovannыkh struktur ahropromыshlennoho kompleksa rehyona: problemы y perspektyvы.

2. Marshall , A. (2008). Pryntsypы эkonomycheskoi nauky. M.: Dyrektmedya Pablyshynh.

3. Leshcheva , M. H. (2007). Razvytye yntehratsyonnыkh protsessov v systeme ahrarnoho predprynymatelstva. Rossyiskoe predprynymatelstvo, 8(1), 95th ser., 13-17.

4. Ahrokholdynhy v Ukraini: dobre chy pohano? Retrieved March 11, 2017, from http://www.ier.com.ua

5. Adyzes, Y. (2007). Upravlenye zhyznennum tsyklom korporatsyy. SPb.: Pyter.

37.

6. Asanova, E. R. (2003). Vertykalnaia yntehratsyia predpryiatyi. Kultura narodov Prychernomoria, 46, 33-

7. Lapin, A. V. (2015). Informatsiina infrastruktura pidpryiemstv z vertykalnoiu formoiu intehratsii . Visn. ZhNAEU, 1(48), 89-97.

8. Nort, D. (1997). Ynstytutы, ynstytutsyonalnыe yzmenenyia y funktsyonyrovanye эkonomyky . M.: Fond эkonomycheskoi knyhy «Nachala».

9. Operatsiini rezultaty ahropromkholdynhu «Astarta-Kyiv» u 2014 rotsi . (n.d.). Retrieved March 11, 2017, from http://astartakiev.com.

10. Stoliarova, E. (2007). Vertykalnaia yntehratsyia kompanyy y teoretycheskye podkhodы k ee obъiasnenyiu. Zhurn. mezhdunar. prava y mezhdunar. otnoshenyi, 1, 93-99.

11. In Ukraine the regions, which lead in harvest of he cereals, have bin named. Retrieved March 11, 2017, from http: // latifundist.com/novosti-urozhaj-onlajn

\author{
Седикова И.А. \\ доктор экономических наук, доцент \\ E-mail: irina-sedikova@rambler.ru \\ Савенко И.И. \\ доктор экономических наук, профессор \\ кафедра менеджмента и логистики \\ Одесская национальная академия пищевых технологий \\ ул. Канатная, 112, г. Одесса, Украина, 65039 \\ E-mail: kaf-ml@mail.ru
}

\section{АНАЛИЗ ОРГАНИЗАЦИОННЫХ ФОРМ СТРУКТУРНЫХ ЭЛЕМЕНТОВ ЛОГИСТИКИ ЗЕРНА}

В статье определены количественные параметры функционирования зернопродуктового рынка Украины, которые формируются под влиянием совокупности организационно-экономических усло- 
вий, к которым мы отнесли структурные элементы различных организационно-правовых фрорм и экономические рычаги, обеспечивающие обменные процессы для стабильного функционирования и эффективного развития всех составляющих производственно-сбытовой системы. Проанализировано и установлено, что внутренняя управляемость логистической системы определяется организационноструктурными, функционально-экономическими и социально-потребительскими факторами, которые фактически и является исходной точкой для совершенствования этой системы. Проанализирован отечественный опыт развития вертикально интегрированных структур зернового подкомплекса. Рассмотрены распространенные модели интегрированных фрормирований зернового рынка. Как известно, агрохолдинги создаются несельскохозяйственным бизнесом. В одних случаях этот бизнес прямо связан с сельским хозяйством, в других - создается компанией, не связанной с сельским хозяйством.

Анализ организационно-экономических условий функционирования логистических систем зернопродуктового подкомплекса следует начинать с рассмотрения существующих организационноправовых форм хозяйствования, осуществляющих хозяйственную деятельность, в соответствии с выбранной организационно-прававовой фрормой.

Функциональными сферами логистики в зернопродуктовом подкомплексе АПК является производство зерна, его реализация зернопроизводителями, закупка переработчиками, хранения зерна с возможной перевалкой в портах для экспорта, переработка зерновой массы и реализация переработанной продукции. Каждая из определенных фрункциональных сфер охватывает сложившуюся совокупность элементов, является следствием трансформационных процессов в экономике или вновь созданных предприятий для удовлетворения бизнес-интересов соответствующих владельцев. Первым на пути следования зернового потока является непосредственные его генераторы - сельскохозяйственные производители. Итак, логистические функции наиболее оптимально реализуются в условиях интегрированных структурных элементов различных организационно-правовых фрорм. Кроме вертикальной интеграции в виде агрохолдингов развивается и горизонтальная интеграция.

Создание объединений предприятий в Украине характерно не только для базовых сфер логистики, которая вертикально или горизонтально интегрирует производителей зерна и его переработчиков, но и для функциональных сфер, осуществляющих транспортировку, перевалку, хранение зерна и обеспечения логистических функций материальными, информационными и финансовыми ресурсами. В этот перечень отнесены Ассоциация аграрных перевозчиков Украины, Украинская логистическая ассоциация, Ассоциация транспортно-экспедиторских и логистических организаций Украины, а также различные объединения транспортно-экспедиторских, фринансовых, страховых, торговых и других компаний.

Следовательно, независимо от форм собственности дальнейшее совершенствование организационно-правовых фрорм структурных элементов логистической системы мы видим в консолидации их усилий на основе различных объединений. Эффрективность этих объединений будет определяться реализацией логистических функций по высоким качеством и меньшими затратами, чем это участники объединения выполняли самостоятельно.

Установлено, что наиболее потенциально конфликтными элементами логистической цепи в зернопродуктовом подкомплексе являются взаимосвязи между производителями зерна и его переработчиками, а также взаимосвязи между производственными предприятиями и финансово-кредитными учреждениями и другими инфраструктурными и институциональными элементами, сопровождающих материальные и обеспечительные (информационные, финансовые и сервисные) потоки.

Ключевые слова: логистика зерна, логистические системы, агрохолдинги, экспорт, сельское хозяйство, вертикально интегрированные формирования.

\author{
Седікова I.O. \\ доктор економічних наук, доцент \\ E-mail: irina-sedikova@rambler.ru \\ Савенко I.I. \\ доктор економічних наук, доцент \\ кафедра менеджменту та логістики \\ Одеська національна академія харчових технологій \\ вул. Канатна, 112, м. Одеса, Україна, 65039 \\ E-mail: kaf-ml@mail.ru
}

\title{
АНАЛІЗ ОРГАНІЗАЦІЙНИХ ФОРМ СТРУКТУРНИХ ЕЛЕМЕНТІВ ЛОГІСТИКИ ЗЕРНА
}

У статті проаналізовано окремі аспекти процесу розвитку вертикально інтегрованих структур зернового підкомплексу, проаналізовано вітчизняний досвід розвитку цих структур зернового підкомп- 
лексу, розглянуто найбільш поширені моделі інтегрованих формувань зернового ринку. У сучасних умовах термін «інтеграція» набуває поліфункціонального характеру і застосовується в описі різних сорер економічної дійсності.

Проведено аналіз організаційно-економічних умов функціонування логістичних систем в зернопродуктового підкомплексу, визначено функціональні сфери логістики в зернопродуктовий подкомплексе. Доведено, що кожна з певних функціональних сфер є наслідком трансформаційних процесів в економіці або новостворених підприємств для задоволення бізнес-інтересів відповідних власників. Доведено, що логістичні функції найбільш оптимально реалізуються в умовах інтегрованих структурних елементів різних організаційно-правових форм. Отже, незалежно від форм власності подальше вдосконалення організаційно-правових форм структурних елементів логістичної системи ми бачимо в консолідації їхніх зусиль на основі різних об'єднань. Ефективність цих об'єднань буде визначатися реалізацією логістичних функцій за високою якістю і меншими витратами, ніж ці учасники об'єднання виконували самостійно. Консолідація фінансових ресурсів об'єднань підприємств створює технікотехнологічні передумови для реалізації логістичних функцій на якісно новому рівні. В Україні співвідношення сучасних силосних потужностей для зберігання зерна і примітивних підлогових технологій відповідно становить 54,2 \% до 44,2 \% інше (1,6 \%). Найбільш потенційно конфліктними елементами логістичного ланцюга в зернопродуктового підкомплексу АПК є взаємозв'язки між виробниками зерна та його переробниками, а також взаємозв'язки між виробничими підприємствами і фрінансово-кредитними установами та іншими інфраструктурними та інституційними елементами, які супроводжують матеріальні і забезпечувальні (інформаційні, фрінансові і сервісні) потоки.

Ключові слова: логістика зерна, логістичні системи, агрохолдинги, експорт, сільське господарство, вертикально інтегровані фрормування.

\section{Література}

1. Аюшеева А.О. Формирование интегрированных структур агропромышленного комплекса региона: проблемы и перспективы: [монография] / А.О. Аюшеева. - Новосибирск: Издательство ЦРНС, 2013. - с. 315.

2. Маршалл А. Принципы экономической науки / А.Маршалл. - М.: Директмедиа Паблишинг. - 2008. 994 c.

3. Лещева М.Г. Развитие интеграционных процессов в системе аграрного предпринимательства / М.Г. Лещева // Российское предпринимательство. - 2007. - № 8-1 (95). - С. 13-17.

4. Агрохолдинги в Україні: добре чи погано? [Електронний ресурс]. - Режим доступу: http://www.ier.com.ua.

5. Адизес И. Управление жизненным циклом корпорации / Ицхак Адизес; пер. с англ. под науч. ред. А. Г. Сеферяна. - СПб.: Питер, 2007. - 384 с.

6. Асанова Э. Р. Вертикальная интеграция предприятий / Э. Р. Асанова // Культура народов Причерноморья. - 2003. - № 46. - С. 33-37.

7. Лапін А. В. Інформаційна інфраструктура підприємств з вертикальною формою інтеграції / А. В. Лапін // Вісн. ЖНАЕУ. - 2015. - № 1 (48) - С. 89-97.

8. Норт Д. Институты, институциональные изменения и функционирование экономики / Д. Норт; пер. с англ. А. Н. Нестеренко. - М.: Фонд экономической книги «Начала», 1997. - 180 с.

9. Операційні результати агропромхолдингу «Астарта-Київ» у 2014 році [Електронний ресурс]. - Режим доступу: http://astartakiev.com.

10. Столярова Е. Вертикальная интеграция компании и теоретические подходы к ее объяснению / Е. Столярова // Журн. междунар. права и междунар. отношений. - 2007. - № 1. - С. 93-99.

11. In Ukraine the regions, which lead in harvest of he cereals, have bin named - Harvest http: // latifundist.com/novosti-urozhaj-onlajn 